\title{
COMUNICAÇÃO
}

BREVE

BRIEF

COMMUNICATION

COMUNICACIÓN

BREVE

\section{A PERCEPÇÃO AUDITIVA DA PARALINGUAGEM DO PACIENTTE APÓS TIREOIDECTOMA SUBTOTAL: ENSINO E PESQUISA EM ENFERMAGEM}

\author{
Aline da Costa Marins
}

Sílvia Teresa Carvalho de Araújo

Ao delinear o objeto de investigação através de bolsa de iniciação científica, com financiamento da Fundação Carlos Chagas Filho de Amparo à Pesquisa do Estado do Rio de Janeiro (FAPERJ), já havíamos adotado como correta a premissa de que a assistência de enfermagem deve ser repleta de conhecimentos científicos capazes de desenvolver a sensibilidade nas relações humanas. A valorização da comunicação, especialmente do tipo não-verbal, define o grau de complexidade das respostas do corpo, como aquelas resultantes da ordem física, biológica, social, espiritual, psíquica e energética do sujeito no processo de enfermagem ${ }^{1}$.

Associando os dados das pesquisas às experiências em campo de estágio supervisionado na graduação, verifiquei que o paciente, durante a recuperação anestésica de tireoidectomia subtotal, experimenta a dor, fadiga ou outra sensação, produzindo um diálogo interno, consciente ou não, que se exterioriza, como conseqüência, através de diferentes manifestações corporais.

Nesta etapa cirúrgica, o ato de cuidar enriquece-se quando o observador, o profissional de enfermagem do centro cirúrgico, percebe e decodifica as expressões não-verbais cinésicas e de paralinguagem do paciente, para que, assim, possa adequar a singularidade do cuidado.

Nessa busca, os gestos, as posturas, as expressões fisionômicas e os sons ganham relevo no cuidado, pois resultam de outras sensações desagradáveis e incômodas sentidas e utilizadas pelos pacientes para se comunicarem. Cabe ao profissional de enfermagem desenvolver, continuamente, habilidades técnicas e humanas para intervir, o que demanda o desenvolvimento de sua capacidade em se comunicar².

Ao elaborar um instrumento de observação de campo, buscamos não só a percepção auditiva da paralinguagem e as cinesias manifestadas pelo paciente, mas também analisar como o profissional de enfermagem percebe e atende as necessidades implíitas nessas manifestações.

Se a paralinguagem é traduzida como diferentes sons do aparelho fonador que não se traduzem em palavras, ao investigá-la de forma sistematizada, compreendemos, juntamente com a cinesia do paciente, suas tentativas de se fazer entender.

A relevância deste estudo traduz-se na possibilidade de abertura dos sentidos, para redimensionar o olhar aos aspectos intersubjetivos presentes na interação com os pacientes submetidos à tireoidectomia subtotal no pós-operatório. Do tipo exploratóriodescritivo, o estudo está utilizando o método de observação não-participante e está sendo realizado no setor de recuperação anestésica (RA) do centro cirúrgico de um hospital de grande porte do Rio de Janeiro.

0 roteiro de observação sistematizada utiliza a vivência adaptada dos sentidos sóciocomunicantes do corpo, criada por Araújo $^{3}$, para exercitar a amplitude dos sentidos. A observação ocorreu durante a primeira hora de recuperação anestésica, e foi realizada, posteriormente, uma entrevista com os pacientes para a compreensão das sensações atribuídas às manifestações observadas.

0 estudo, com duração prevista para dois anos (junho/2005 - maio/ 2007), foi aprovado pelo CEP do cenário de pesquisa e encontra-se em andamento. Até agora contempla a observação e entrevista com seis sujeitos entre 20 e 60 anos, de ambos os sexos, rastreados no mapa operatório e observados quanto ao tipo de cinesia corporal e paralinguagem. Esses pacientes, apresentaram grande mobilidade corporal, o que 
pode estar influenciado não só pelos efeitos medicamentosos, como também intensificados pelos efeitos resultantes do distúrbio endócrino manifestado por estes pacientes.

Quanto à decodificação da paralinguagem manifestada pelos sujeitos, pode-se perceber a tosse e o grunhido. Os sinais paralingüísticos demonstram sentimentos, características da personalidade, atitudes, relacionamento interpessoal e autoconceito ${ }^{4}$. Os sujeitos da pesquisa, por terem sido submetidos a um procedimento cirúrgico próximo às cordas vocais, inicialmente apresentavam uma dificuldade de verbalização.

As cinesias mais significativas foram mobilidade dos braços, pescoço, cabeça, mãos, abertura parcial e total dos olhos, elevação de tronco em $45^{\circ}$ e $90^{\circ}$. Quanto às suas validações, podemos destacar a sonolência, dor, agitação, incômodo, chamamento, ansiedade, agradecimento, rejeição, proteção e atenção.

A maioria das manifestações não-verbais foram percebidas pela equipe de enfermagem que os assistia. Entretanto, 0 atendimento às mesmas era tardio, efetuado somente após três ou mais tentativas do paciente, muitas vezes seguidas de verbalização. A comunicação deve estabelecer uma interação efetiva com o paciente, com o objetivo de oferecer-lhe apoio, conforto e informação, e despertar seu sentimento de confiança e de auto-estima ${ }^{5}$.

0 setor de recuperação anestésica possui como característica uma equação que relaciona inúmeras variáveis relacionadas a ambiente, pessoas e tarefas, o que pode resultar em um cuidado muitas vezes mecânico, técnico e rotineiro.

Este estudo incluirá mais dez sujeitos e buscará ampliar e aprofundar a análise. Neste sentido, é importante priorizar a percepção da comunicação não-verbal no cuidado ao paciente submetido à tireoidectomia subtotal, pois, apesar de ele possuir uma certa limitação orgânica devida ao efeito anestésico, consegue comunicar-se através de movimentos corporais e sons a serem levados em consideração, para que suas necessidades sejam atendidas com qualidade.

Palavras-chave: Percepção Auditiva. Comunicação. Tireoidectomia. Pesquisa em Enfermagem. Educação em Enfermagem.

\section{Referências}

1. Figueiredo NMA, Machado WCA, Porto IS. Dama de Negro X Dama de Branco: 0 cuidado na fronteira vida-morte. Rev Enferm UERJ 1995 out; 3 (2): 139- 49.

2. Saes SC, Araújo STC. 0 cuidado de enfermagem através dos sentidos corporais do cliente em diálise peritoneal: uma abordagem sociopoética. Esc Anna Nery Rev Enferm 2004 ago; 8(2): 259-66.

3. Araújo STC. Os sentidos corporais dos estudantes no aprendizado da comunicação não-verbal do cliente na recepção pré-operatória: Uma semiologia da expressão através da sociopoética [tese de doutorado]. Rio de Janeiro (RJ) Escola de Enfermagem Anna Nery/UFRJ; 2000.

4. Silva MJP. Comunicação tem remédio: a comunicação nas relações interpessoais em saúde. São Paulo (SP): Ed Loyola; 2002.

5. Stefanelli MC. Comunicação com paciente: teoria e ensino. $2^{\text {a }}$. ed. São Paulo (SP): Robe Ed; 1993.

\section{Sobre as Autoras}

\section{Aline da Costa Marins}

Escola de Enfermagem Anna Nery da Universidade Federal do Rio de Janeiro.e-mail: adacostamarins@yahoo.com

\section{Sílvia Teresa Carvalho de Araújo}

Coordenadora e orientadora do Projeto. Escola de Enfermagem Anna Nery da Universidade Federal do Rio de Janeiro. 


\section{THE ADUDITORY PERCEPTION OF THE PARALANGUAGE OF THE PATIENT AFTER SUBTOTAL THYROIDECTOMY: EDUCATION AND RESEARCH IN NURSING}

When delineating the object of inquiry through scientific initiation scholarship, with financing of the Carlos Chagas Filho Foundation of Support to the Research of the State of Rio de Janeiro (FAPERJ), we had already adopted as correct the premise of that the nursing assistance must be fulfilled of scientific knowledge capable to develop sensitivity in the human relations. The valuation of the communication, especially of the non-verbal type, defines the degree of complexity of the answers of the body, as those resultants of the physical, biological, social order, spiritual, psychic and energy of the citizen in the nursing process.

Associating the data of the research to the experiences in field of period of training supervised in the graduation, I verified that the patient, during the anesthetical recovery of thyroidectomy subtotal, tries pain, fatigue or another sensation, producing an internal, conscientious dialogue or not, that if exteriorize, as consequence, through different corporal manifestations.

In this surgical stage, the act to take care of is become rich when the observer, the professional of nursing of the surgical center, perceives and decodes the cinesics not-verbal expressions and of paralanguage of the patient, so that, thus, he can adjust the singularity of the care. In this search, the gestures, the phisyonomics positions, expressions and the sounds gain relief in the care, therefore they result of other ackward and bothering sensations felt and used by the patients to be communicated. It fits to the nursing professional to develop, continuously, abilities techniques and human beings to intervine, what demand the development of its capacity in communicating themselves.

When elaborating an instrument of field comment, we not only search the auditory perception of the paralanguage and the cinesys revealed for the patient, but also analyzing as the nursing professional perceives and takes care of the implicit necessities in these manifestations.

If the paralanguage is translated as different sounds of the voicer device that are not expressed in words, when investigating it in a systemize form, we understand, along with the cinesy of the patient, its attempts in been understand.

The relevance of this study is expressed in the possibility of opening of the directions, to redimentionning the look to the intersubjetives aspects in the interaction with the patients submitted to the thyroidectomy subtotal in the postoperative. Of the type exploratory-description, the study it is using the comment method non-participant and is being carried through in the sector of anesthetical recovery $(\mathrm{RA})$ of the surgical center of a important hospital of Rio de Janeiro.

The script of systemize observation uses the suitable experience of the partnercommunicatives senses of the body, created for Araújo, to exercise the scope of the directions. The observation occurred during the first hour of anesthetical recovery, and was carried through, later, an interview with the patients for the understanding of the sensations attributed to the observed manifestations.

The study, with duration foreseen for two years (June 2005 - May 2007), it was approved by the CEP of the research scene and meets in progress. So far it contemplates the comment and interview with six citizens between 20 and 60 years old, of both the genders, tracked in the operatory map and observed by the type of corporal cinesy and paralanguage. These patients, had presented the great corporal mobility, what it can be influenced not alone for the medicine effect, as also intensified for the resultant effect of the endocrin riot revealed by these patients. 
About the decodification of the paralanguage revealed for the citizens, it can be perceived with cough and grunt. The paralanguistics signals demonstrate feelings, characteristics of the personality, attitudes, interpersonal relationship and self-concept. The citizens of the research, for having been submitted to a surgical procedure next to the vocal ropes, initially presented a verbalization difficulty.

About the decodification of the paralanguage revealed for the citizens, it can be perceived with cough and grunt. The paralanguistics signals demonstrate feelings, characteristics of the personality, attitudes, interpersonal relationship and self-concept. The citizens of the research, for having been submitted to a surgical procedure next to the vocal ropes, initially presented a verbalization difficulty.

The cinesys most significant had been mobility of the arms, neck, head, hands, partial and total opening of the eyes, rise of trunk in $45^{\circ}$ and $90^{\circ}$. How much to its validations, we can detach the sleepiness, pain, agitation, bother, calling, anxiety, gratefulness, rejection, protection and attention.

The majority of the not-verbal manifestations had been perceived by the nursing team that attended them. However, the attendance to the same ones was delayed, only effected after three or more attempts of the patient, many followed times of verbalization. The communication must establish an interaction accomplishes with the patient, the objective to offer support, comfort and information to it, and to awake its reliable feeling and of self-steem.

The sector of anesthetical recovery possesss as characteristic an equation that relates innumerable related 0 variable the environment, people and tasks, what it can result in a care many times mechanical, technician and routinist.

This study will include more ten citizens and it will search to extend and to deepen the analysis. In this direction, it is important to prioritize the perception of the not-verbal communication in the care to the patient submitted to the thyroidectomy subtotal, therefore, although it to possess a certain organic limitation due to the effect anaesthetic, obtains to communicate through corporal movements and sounds to be led in consideration, so that its necessities are taken care of with quality.

Keywords: Auditory Perception. Communication. Thyroidectomy. Nursing Research. Education, Nursing.

\section{References}

1. Figueiredo NMA, Machado WCA, Porto IS. Dama de Negro X Dama de Branco: 0 cuidado na fronteira vida-morte. Rev Enferm UERJ 1995 out; 3 (2): 139- 49.

2. Saes SC, Araújo STC. 0 cuidado de enfermagem através dos sentidos corporais do cliente em diálise peritoneal: uma abordagem sociopoética. Esc Anna Nery Rev Enferm 2004 ago; 8(2): 259-66.

3. Araújo STC. Os sentidos corporais dos estudantes no aprendizado da comunicação não-verbal do cliente na recepção pré-operatória: Uma semiologia da expressão através da sociopoética [tese de doutorado]. Rio de Janeiro (RJ) Escola de Enfermagem Anna Nery/UFRJ; 2000.

4. Silva MJP. Comunicação tem remédio: a comunicação nas relações interpessoais em saúde. São Paulo (SP): Ed Loyola; 2002.

5. Stefanelli MC. Comunicação com paciente: teoria e ensino. $2^{\mathrm{a}}$. ed. São Paulo (SP): Robe Ed; 1993.

\section{About the Authors}

\section{Aline da Costa Marins}

Escola de Enfermagem Anna Nery da Universidade Federal do Rio de Janeiro.e-mail: adacostamarins@yahoo.com

\section{Sílvia Teresa Carvalho de Araújo}

Co-ordinator and supervisor of the Project. Escola de Enfermagem Anna Nery from the Universidade Federal do Rio de Janeiro. 


\section{EL OPINIÓN AUDTIVA DE LA PARALENGUA E DEL PACIENTE DESPUÉS TIROIDECTOMIA PARCIAL: EDUCACIÓN Y INMESTIGACIÓN EN ENFERMERÍA}

Al delinear el objeto de la investigación a través de la bolsa de iniciación científica, con el financiamiento de la Fundación Carlos Chagas Filho del Amapro a la Investigación del Estado de Rio de Janeiro (FAPERJ), habíamos adoptado ya como correcto la premisa de que la ayuda de la enfermería debe ser repleta del conocimiento científico capaz para desarrollar sensibilidad en los seres humanos de las relaciones. La valuación de la comunicación, especialmente del tipo no-verbal, define el grado de complejidad de las respuestas del cuerpo, como esos resultados de la orden, física, biologica, social, espiritual, psiquica y energetica del ciudadano en el proceso de enfermería.

Asociando los datos de la investigación a las experiencias en el campo del período del entrenamiento supervisado en pregrado, verificamos que el paciente, durante la recuperación anestésica subtotal del tireoidectomia, intenta dolor, fatiga u otra sensación, produciendo un diálogo interno, concienzudo o no, que si exterioriza, como consecuencia, con diversas manifestaciones corporales.

En esta etapa quirúrgica, el acto para tomar cuidado llega a ser rico cuando el observador, profesional de enfermería del centro quirúrgico, percibe y descifra las expresiones no-verbales cinésicas y del paralenguaje del paciente, de modo que, así, él pueda ajustar la singularidad del cuidado. En esta búsqueda, los gestos, las posiciones, las expresiones fisionómicas y los sonidos ganan la enfasis en el cuidado, por lo tanto resultan de otras sensaciones desagradables y incomodas sentidas y utilizadas por los pacientes que se comunicarán.

El profesional de enfermería debe desarrollar, continuamente, a las técnicas de las capacidades y a los seres humanos al intervenir, qué demanda el desarrollo de su capacidad en si comunicar. Al elaborar un instrumento de observación del campo, buscamos no sólo la opinión auditiva de la paralenguaje y las cinesias reveladas por el paciente, sino que también analizar como el profesional de enfermería percibe y toma el cuidado de las necesidades implícitas en estas manifestaciones.

Si la paralenguaje se traduce como diversos sonidos del dispositivo fonador que no sean expresados em palabras, al investigarlo de forma sistematizada, entendemos, junto con la cinesia del paciente, sus tentativas de se haceren entender.

La importancia de este estudio se expresa en la posibilidad de abertura de los sentidos, a redimensionar la mirada a los aspectos intersubjetivos presetes en la interacción con los pacientes sometidos a la tireoidectomia subtotal en el postoperatorio. Del tipo exploratorio-descriptivo, el estudio está utilizando el metodo no-participante y está siendo realizado en el sector de recuperación anestésica (RA) del centro quirúrgico de un importante hospital de Rio de Janeiro.

El rotero de observación sistematiza utiliza la experiencia adaptada de los sentidos de sóciocomunicantes del cuerpo, creados por Araújo, para ejercitar el alcance de los sentidos. La observación ocurrió durante la primera hora de la recuperación anestésica, fué realizada, más adelante, una entrevista con los pacientes para la comprensión de las sensaciones atribuidas a las manifestaciones observadas.

El estudio, con duración prevista para dos años (junio/2005 - mayo/2007), fue aprobado por el CEP de la escena de la investigación y está en marcha. Comtempla hasta ahora comentario y entrevista con seis ciudadanos entre 20 y 60 años, ambos sexos, rastreados en el mapa quirúrgico y observado por el tipo de cinesia corporal y paralenguaje. Estos pacientes, habían presentado 
gran movilidad corporal, qué puede ser influenciada no solamente para el efecto de los medicamientos, según lo también intensificado para el efecto resultante del alboroto endócrino revelado por estos pacientes.

Sobre la decodificación da paralenguaje revelado para los ciudadanos, puede ser percibido con tos y ronco. Las señales de los paralenguisticos demuestran sensaciones, características de la personalidad, actitudes, relación interpersonal y concepto de sí mismo. Los ciudadanos de la investigación, por tener sido sometido a un procedimiento quirúrgico al lado de las cuerdas vocales, presentaran inicialmente una dificultad de verbalization.

Las cinesias más significativas habían sido movilidad de los brazos, el cuello, la cabeza, las manos, la abertura parcial y total de los ojos, la subida del tronco en $45^{\circ}$ y $90^{\circ}$. Cuánto a sus validaciones, podemos separar el sonolencia, el dolor, la agitación, la incomodidad, llamar, la ansiedad, la gratificación, el rechazamiento, la protección y la atención.

Al equipo de enfermería fué percibido que la mayoría de las manifestaciones no-verbales que les atendieron. Sin embargo, la mismas atenciones fueran retrasadas, sólo estuvo efectuada después de que tres o más tentativas del paciente, muchas siguieran épocas de verbalização. La comunicación debe establecer una interacción con el paciente, objetivo para ofrecer ayuda, comodidad e información, y para despertar su sensación confiable de autoestima.

El sector de recuperación anestésica posue como característica una ecuación que relaciona innumerables variables relacionada al ambiente, la gente y las tareas, qué puede dar lugar a un cuidado muchas veces mecánicas, técnico y routinas.

Este estudio incluirá más diez ciudadanos y buscará ampliar y profundizar el análisis. En esta dirección, es importante dar la prioridad a la opinión de la comunicación no-verbal en el cuidado al paciente sometido a la tireoidectomia subtotal, por lo tanto, aunque él para poseer cierta limitación orgánica debido al efecto del anestésico, pues, aún para comunicarse a través de los movimientos corporales y de los sonidos que se conducirán en la consideración, para tomar sus necesidades cuidado con de la calidad.

Palabras clave: Percepción Auditiva. Comunicación. Tiroidectomía. Investigación en Enfermería. Educación en Enfermería.

\section{Referencias}

1. Figueiredo NMA, Machado WCA, Porto IS. Dama de Negro X Dama de Branco: 0 cuidado na fronteira vida-morte. Rev Enferm UERJ 1995 out; 3 (2): 139- 49.

2. Saes SC, Araújo STC. 0 cuidado de enfermagem através dos sentidos corporais do cliente em diálise peritoneal: uma abordagem sociopoética. Esc Anna Nery Rev Enferm 2004 ago; 8(2): 259-66.

3. Araújo STC. Os sentidos corporais dos estudantes no aprendizado da comunicação não-verbal do cliente na recepção pré-operatória: Uma semiologia da expressão através da sociopoética [tese de doutorado]. Rio de Janeiro (RJ) Escola de Enfermagem Anna Nery/UFRJ; 2000.

4. Silva MJP. Comunicação tem remédio: a comunicação nas relações interpessoais em saúde. São Paulo (SP): Ed Loyola; 2002.

5. Stefanelli MC. Comunicação com paciente: teoria e ensino. $2^{\mathrm{a}}$. ed. São Paulo (SP): Robe Ed; 1993.
Sobre las Autoras

\section{Aline da Costa Marins}

Escola de Enfermagem Anna Nery da Universidade Federal do Rio de Janeiro.e-mail: adacostamarins@yahoo.com

\section{Sílvia Teresa Carvalho de Araújo}

Coordinadora y orientadora del Proyecto. Escola de Enfermagem Anna Nery da Universidade Federal do Rio de Janeiro. 
